\title{
PEAK GROUND ACCELERATIONS RECORDED IN THE 1968 INANGAHUA EARTHQUAKE AND SOME ATTENUATION IMPLICATIONS
}

\author{
David J. Dowrick1 and S. Sritharan1
}

\begin{abstract}
SUMMARY
The $M_{s} 7.41968$ Inangahua earthquake was the largest New Zealand earthquake to have occurred from 1934 to 1992. The valuable strong motion data obtained on scratchplate acceleroscopes has not previously been adequately described. Filling that information gap, this paper lists the re-evaluated peak ground accelerations and examines their attenuation properties. It is shown that the accelerations from this event are much stronger over a wide range of source distances than those obtained using attenuation models for the western USA. Similar results have been found for a number of more recent New Zealand events in another study.
\end{abstract}

\section{INTRODUCTION}

The main shock of the Inangahua earthquake of 23(UT) May 1968 occurred in the Southern Alps of New Zealand, epicentre $41.8^{\circ} \mathrm{S} 172.0^{\circ} \mathrm{E}$. With a magnitude of $\mathrm{M}_{\mathrm{s}}=7.4$ $[1,2]$ it is the largest event to have occurred within the New Zealand land area in the period March 1934 to November 1992. This large earthquake occurred in the early days of strong motion recording in New Zealand, and perhaps because of this the strong ground motion records obtained have not previously been fully written up. A hint of such records was given by Stephenson [3] who stated in a preliminary report that "accelerations of the order of $0.3 \mathrm{~g}$ to $0.5 \mathrm{~g}$ occurred at close in areas such as Murchison, Reefton, and Westport". These figures exceed further preliminary estimates for Reefton $(0.35 \mathrm{~g})$, Greymouth $(0.30 \mathrm{~g})$ and Westport $(0.25 \mathrm{~g})$ given by Adams et al. [4], and a single value for Reefton $(0.35 \mathrm{~g})$ given by Sheppard et al. [5]. To add to the confusion two different values $(0.35 \mathrm{~g}$ and $0.60 \mathrm{~g})$ were given for Reefton in the Canterbury Engineering Journal [6]. In 1986 PGA data from 12 sites were published in graphical form only [7], Reefton's peak ground acceleration (PGA) plotted at $0.3 \mathrm{~g}$.

As the above publications inadequately describe a valuable data set, this paper sets out to redress the situation by presenting and discussing the full set of carefully recalculated (PGA) data.

\section{THE DATA}

At the time of the earthquake there existed a nationwide network of Scratchplate Acceleroscopes (SP) of which 15 recorded the mainshock. In addition two Mechanical Optical
(MO1) accelerographs were situated within triggering range, notably one near the epicentre at Westport which unfortunately was not operational, and a further one at the DSIR Physics and Engineering Laboratory (PEL), Lower Hutt, on which a record was obtained. The whole data set is given in Table 1.

Fortunately all the original SP recordings had been safely stored so that they could be re-photographed for remeasuring the amplitudes and re-calculating the accelerations using the original instrument calibrations. Figure 1 shows a photograph of the strongest SP record, namely that from Reefton. Two features of such a record deserve some consideration, i.e.

(i) determining the origin of the trace,

(ii) choice of component direction.

The origin of the trace is often uncertain, so that different people reading a given trace obtain different amplitudes. Errors from this source are considered to be less than 10 percent.

The choice of component directions for measuring PGA's is important in some cases where strong site directionality is evident. In order to relate PGAs of scratchplate records to the two horizontal components obtained from time-history accelerographs, we arbitrarily measure the peak components in the NS and EW directions as though these were accelerograph axes. In addition the polar peak is also measured.

It is noted that a scale factor error of 0.5 appears to have been made in most of the previous measurements of the Reefton record. This confusion may have occurred because 
TABLE 1: Strong motion data from the 1968 Inangahua earthquake.

\begin{tabular}{|c|c|c|c|c|c|c|c|c|}
\hline & Site Name & $\begin{array}{l}\text { Shorte } \\
\text { distance }\end{array}$ & $\begin{array}{l}\text { m rizontal } \\
\text { m source }\end{array}$ & & $\operatorname{PGA}(\mathrm{g})$ & & $\begin{array}{l}\text { Predominant } \\
\text { Ground Conditions }\end{array}$ & $\begin{array}{l}\text { Approx. } \\
\text { Depth } \\
\text { to }\end{array}$ \\
\hline & & Model G & Model S & N-S & E-W & Polar & & (m) \\
\hline 1 & Reefton & 15 & 22 & 0.47 & 0.58 & 0.61 & Gravel & 30 \\
\hline 2 & Murchison & 28.5 & 24 & 0.29 & 0.36 & 0.37 & Gravel & 250 \\
\hline 3 & Westport & 29 & 21.5 & 0.30 & 0.30 & 0.34 & $\operatorname{Mud}(5 \mathrm{~m}) /$ gravel & $>100$ \\
\hline 4 & Greymouth & 73.5 & 73.5 & 0.22 & 0.39 & 0.40 & Sandy gravel & 40 \\
\hline 5 & Golden Downs & 78 & 73.5 & 0.086 & 0.092 & 0.092 & Gravel & 40 \\
\hline 6 & Hokitika & 108.5 & 108.5 & 0.16 & 0.17 & 0.19 & Sand(5m)/gravel & 100 \\
\hline 7 & Motueka & 112 & 107.5 & 0.072 & 0.075 & 0.087 & Sand/silt/gravel & 300 \\
\hline 8 & Nelson & 121 & 116 & 0.078 & 0.080 & 0.084 & Sand/clay/gravel & 50 \\
\hline 9 & Cheviot & 150 & 155 & 0.045 & 0.049 & 0.055 & Clay/gravel & 15 \\
\hline 10 & Havelock & 157.5 & 152 & 0.030 & 0.030 & 0.035 & Clay(stiff) & 2 \\
\hline 11 & Kaikoura & 158 & 153 & 0.052 & 0.050 & 0.061 & Sand/gravel & 10 \\
\hline 12 & Picton & 176.5 & 171.5 & 0.044 & 0.028 & 0.044 & Gravel/sand/silt & 20 \\
\hline 13 & $\begin{array}{l}\text { Christchurch } \\
\text { (Airport) }\end{array}$ & 176 & 184.5 & 0.013 & 0.011 & 0.013 & Gravel & c. 700 \\
\hline 14 & $\begin{array}{l}\text { Christchurch } \\
\text { (Chem.Dept) }\end{array}$ & 184 & 192.5 & 0.031 & 0.018 & 0.031 & Gravel & 800 \\
\hline 15 & Levin & 304 & 298.5 & 0.022 & 0.020 & 0.022 & Gravel & 300 \\
\hline 16 & PEL & 251 & 246 & c. $0.015^{*}$ & c. $0.015^{*}$ & - & Alluvial/marine & 20 \\
\hline
\end{tabular}

NOTE: $\quad$ indicates data from MO1 accelerograph; all other data are from scratchplate acceleroscopes.

the record was so large that it could be photographically magnified only 50 times instead of the standard 100 times, so as to fit on a standard size of photographic print.

It is a historical curiosity that the accelerations recorded at Reefton were the strongest recorded in the world at that time, and would have been considered with some surprise and some disbelief had they been firmly established and proclaimed in 1968. Now, of course, PGAs of $0.6 \mathrm{~g}$ are almost commonplace.

\section{Recording Site Ground Conditions}

Brief descriptions of the ground conditions and depth to bedrock at the recording sites are given in Table 1, from which it can be seen that most of the sites are stiff or firm. Five sites are at the soft end of the stiffness scale, i.e. Motueka, Nelson, PEL, Westport and Hokitika in approximate increasing order of stiffness.

\section{Distances from the Source}

The earthquake source was a reverse fault rupture Multidisciplinary studies [8] have shown that the rupture surface is difficult to define with great geometrical accuracy. It is likely to be dipping at about $45-50^{\circ}$ in a northwesterly direction, and may have been strongly curved along its strike, two simplified linear models suggesting that the strike lies in the range $027^{\circ}-052^{\circ}$. The estimated length of the rupture lies in the range $15-30 \mathrm{~km}$ (the rupture depth is noted later). In this study two alternative source models are examined for determining distances from the source. Distances for the geodetic model (Model $G$ ) and the seismological model (Model S) are given in Table 1. A horizontal length of 27 $\mathrm{km}$ was adopted for Model $\mathrm{G}$, rather than its full $30 \mathrm{~km}$, because the slip at its south end was tapered to zero [8]. The $45^{\circ}$ dip on the fault plane adds a further complexity, but for the purposes of this study, it suffices to measure horizontal distances from the vertical projection of a horizontal line in 


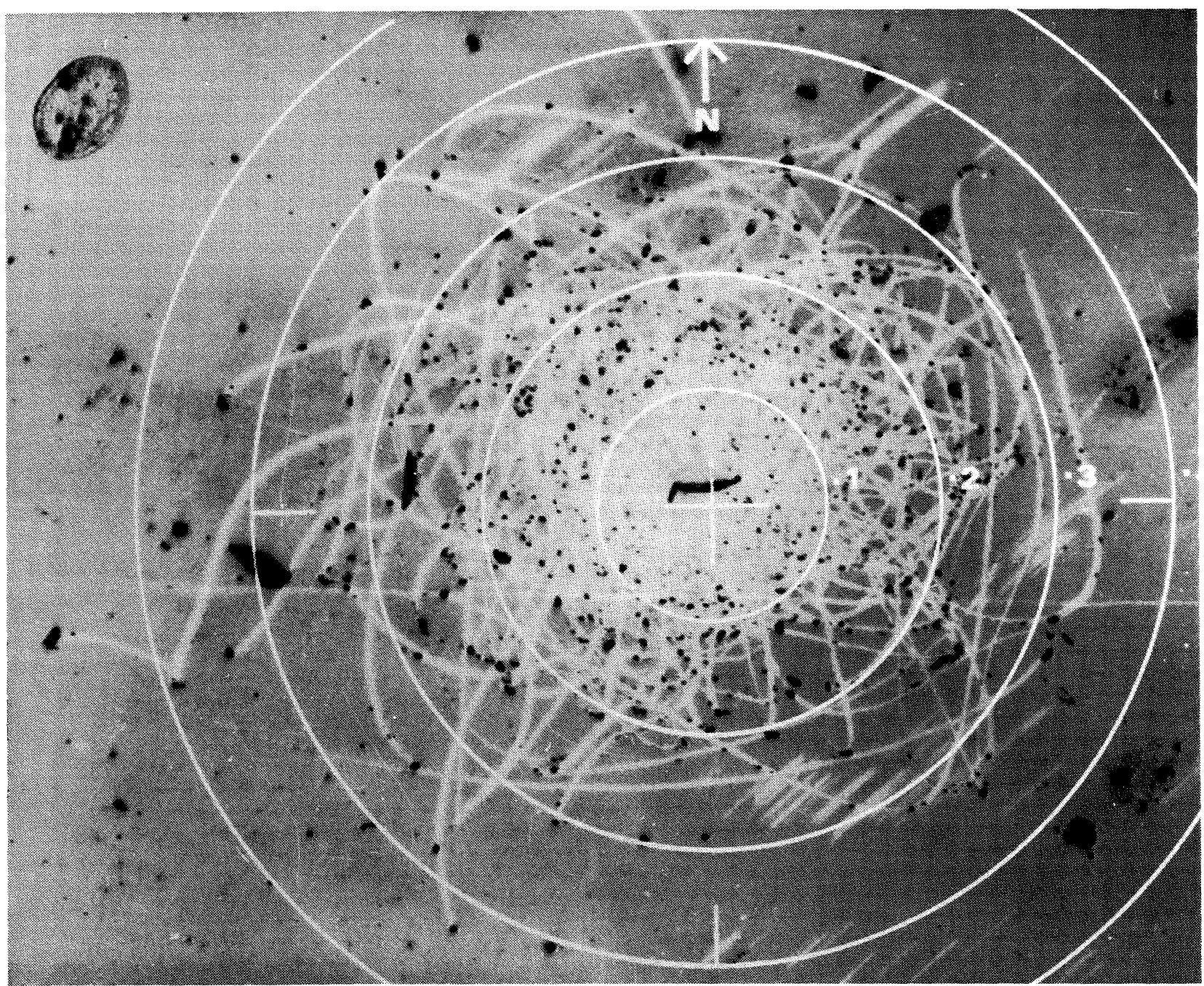

Figure 1 Horizontal trace from the scratchplate accelerascope at Reefton in the 1968 Inangahua earthquake, with peak polar acceleration of $0.61 \mathrm{~g}$.

the fault plane, half way down the rupture surface, as shown in Figure 2.

\section{ATTENUATION OF PEAK GROUND ACCELERATIONS}

In order to examine the attenuation of PGA in this event an attenuation expression was adopted of the form used by various workers, e.g. Joyner and Boore [9] and Ambraseys and Bommer [10], i.e.

$$
\log _{10} P G A=a+b M+c r+d \log _{10} r
$$

where a, b, c, d are empirical regression coefficients, $M$ is magnitude

$r$ is distance from the source, in $\mathrm{km}$, such that

$$
r=\left(r_{h}^{2}+h_{b}^{2}\right)^{1 / 2}
$$

where $r_{h}$ is the shortest horizontal distance from the vertical projection of the source (rupture surface), and $h_{s}$ is a depth term.
The choice of the most appropriate definition of $h_{s}$ for regression analyses is a matter of some debate. Joyner \& Boore [9] consider that $h_{s}$ allows for a number of effects, i.e. that the source of the peak motion may not be the closest point on the rupture, limiting effects of ground strength, and directivity. When considering multiple regressions of sets of events having narrow depth bands, one approach is to determine a mean value of $h_{s}$ from the regression analysis. For example for shallow western USA events Joyner and Boore [9] found a mean value of $7.3 \mathrm{~km}$ from their regression analysis, as in equation (5) below, while Ambraseys and Bommer [10] found $h_{8}=6.0$ fitted their shallow European data. When near source modelling is not a great concern this approach is adequate, as modest changes in $h_{s}$ make insignificant differences to the regression curve at middle and far-field distances (compare curves 1 and 2 in Figure 3).

Alternative source models of the Inangahua earthquake [8] show that the rupture surface probably extended over the depth range from either $0.5-10.5 \mathrm{~km}$ or $5-15 \mathrm{~km}$. As our chief concern here is to consider the overall pattern of the attenuation curve at source distances of about $20 \mathrm{~km}$ and 


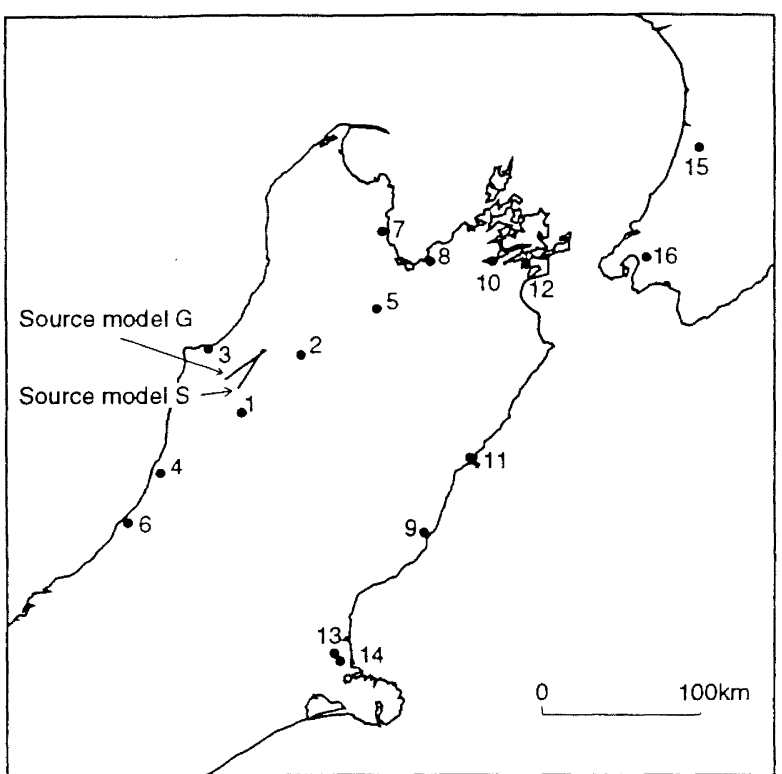

Figure 2 Fault nupture locations plotted at centroid depth for two altemative source models, and relationship to the nearer recording sites The site numbers correspond to those given in Table 1. greater, it suffices for us to examine the effects of using $h_{s}=$ 5 and $10 \mathrm{~km}$ in equation (2), which are possible depths to the top or centroid of the rupture surface, and are likely values representing overall effective source depth.

For finding a best fit regression curve of the above form for a set of data obtained from a single event, equation (1) reduces to

$$
\log P G A=a^{1}+c r+d \log r
$$

where $a^{1}, c$ and $d$ are empirical regression coefficients.

Regression analyses were carried out using the PGA and distance data from Table 1. Firstly, we will examine the effect of uncertainties in the source model, by comparing regressions obtained using distances from Model $G$ and Model S. Using the stronger of the two orthogonal components of PGA, three regression curves are plotted in Figure 3, as follows:

\begin{tabular}{|c|c|c|}
\hline No. & Horizontal Distances & $\mathrm{h}_{\mathrm{s}}$ \\
\hline 1 & Source model S & $10 \mathrm{~km}$ \\
2 & Source model S & $5 \mathrm{~km}$ \\
3 & Source model G & $5 \mathrm{~km}$ \\
\hline
\end{tabular}

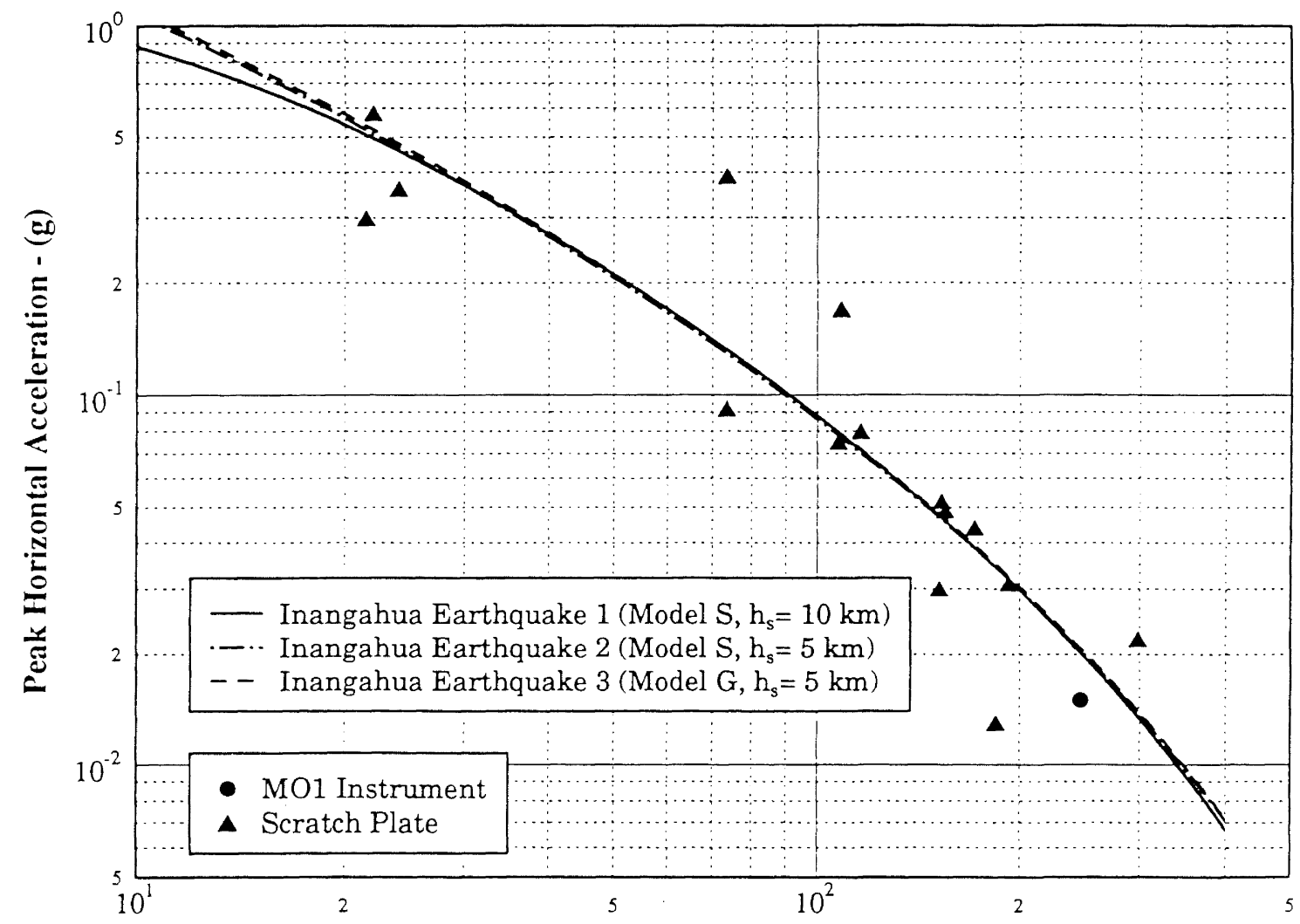

Nearest Horizontal Distance to the Fault Rupture - (km)

Figure $3 \quad P G A$ data (stronger horizontal component) and mean regression curves using distances from alternative source models (data plotted as for Model $S$ and coefficient $d=-1.0$ ). 
The PGA data points in Figure 3 are plotted at distances corresponding to Model $\mathrm{S}$, while those for Model $\mathrm{G}$ are plotted in Figure 4. The influential differences are for the three closest points. As we are not concerned here with modelling the near source region it can be seen that the uncertainties in the source model have no significant effect on the overall regression results (for distances $r_{h}>20 \mathrm{~km}$, say).

In regression analyses using equation (3) the coefficients $a^{1}$, $c$ and $d$ may all be estimated from the regression or the value of $\mathrm{d}$ may be constrained to a favoured (theoretical) value. For Figure 3, it was assumed that $\mathrm{d}=-1.0$, as adopted by Joyner and Boore [9] and Ambraseys and Bommer [10].

As discussed elsewhere $[10,11]$, the question regarding the most appropriate value of the attenuation coefficient $d$ is unresolved. An alternative value, if geometric spreading is confined to the Airy phase, is $d \approx-0.8[10]$. This value has been used for plotting Figure 4. For our data set, this results in a regression curve that lies between that obtained using $d$ $=-1$ and that obtained if $d$ is unconstrained. Such modest differences in the possible regression curves do not affect the overall conclusions of this study.

It is of interest to compare the Inangahua regression curve with those obtained using western USA attenuation models. Firstly, let us consider that of Joyner and Boore [9], i.e. $\log _{10}(\mathrm{PGA})_{\mathrm{s}}=-1.02+0.249 \mathrm{M}_{\mathrm{w}}-0.00255 \mathrm{r}-\log _{10} \mathrm{r}(4)$

where $\quad r=\left(r_{h}^{2}+7.3^{2}\right)^{1 / 2}$

(PGA) $)_{s}$ is the stronger of the two horizontal components in $\mathrm{g}, \mathrm{M}_{\mathrm{w}}$ is the moment magnitude, and $\mathrm{r}$ is in $\mathrm{km}$.

For the Inangahua earthquake, Anderson et al. [12] found a seismic moment $\mathrm{M}_{\mathrm{o}}=4.9 \times 10^{19} \mathrm{Nm}$, which corresponds to $\mathrm{M}_{\mathrm{w}}$ $=7.1$. This moment neglects an arguable third subevent [13], which if included increases the moment by $60 \%$, thus giving $\mathrm{M}_{\mathrm{w}}=7.3$. These $\mathrm{M}_{\mathrm{w}}$ values compare with the $\mathrm{M}_{\mathrm{s}}=7.4$ determined for this event $[1,2]$.

For the purposes of comparison equation (4) is plotted in Figure 4 for magnitude values 7.1 and 7.4. The mean $\pm \sigma$ curves are also plotted for the $\mathrm{M}=7.4$ model. In comparing the Joyner and Boore model with the Inangahua regression curve, it is clear that the Inangahua event is much stronger at all distances than the Joyner and Boore model, regardless of which magnitude value is the most appropriate. The Inangahua mean curve is stronger than the $M=7.4$ mean + $\sigma$ curve at most distances.

Next let us compare the Inangahua regression curve with that obtained using Campbell's [14] constrained model, for the western USA, given by

$$
(P G A)_{m}=0.0185 \exp (1.28 \mathrm{M})\left[r_{f}+0.147 \exp (0.732 \mathrm{M})\right]^{-1.75}(6)
$$

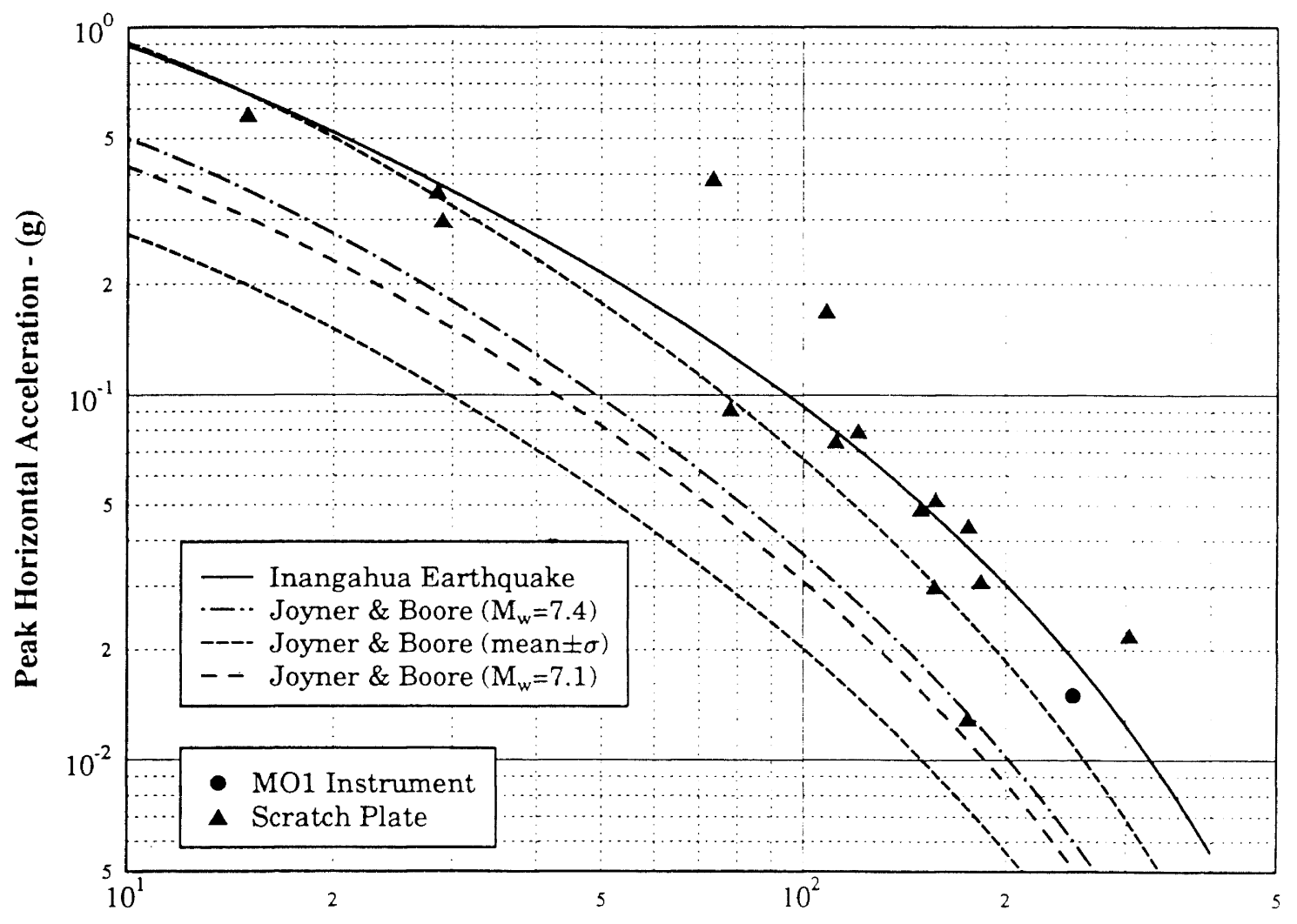

Nearest Horizontal Distance to the Fault Rupture - (km)

Figure $4 P G A$ data (stronger horizontal component) and mean regression curve for source model $G$, $d=-0.8$ compared with model of Joyner and Boore [9]. 


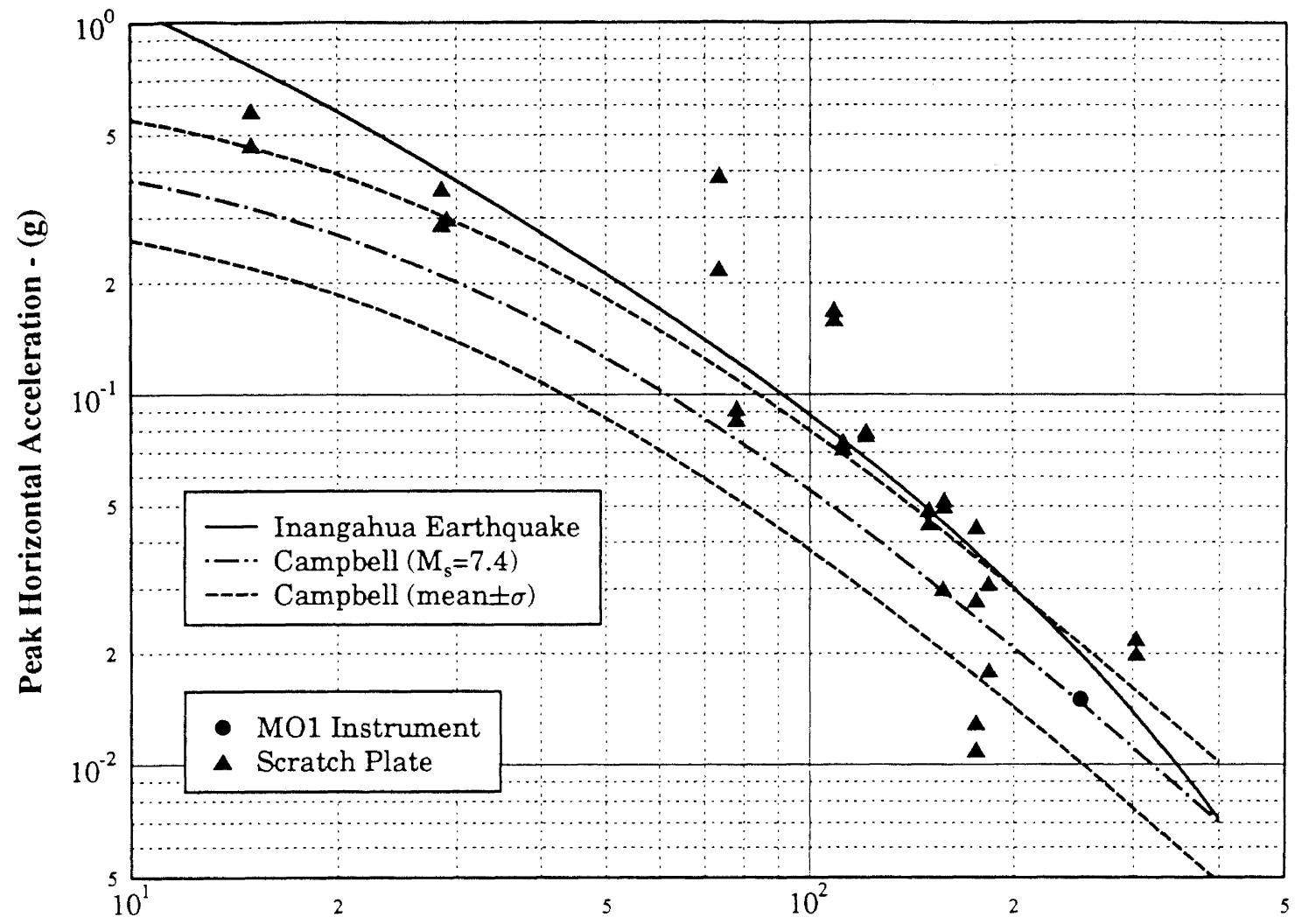

Nearest Horizontal Distance to the Fault Rupture - $(\mathrm{km})$

Figure $5 \quad P G A$ data (both horizontal components) and mean regression curve for source model $G, d=-1.0$, compared with model of Campbell [13] increased for reverse fault effect.

where (PGA) $)_{m}$ is the mean of the two horizontal components of PGA in $g ; M$ is $M_{s}$ (in this case); $r_{f}$ is the shortest distance to the fault rupture (slope distance) in $\mathrm{km}$.

Campbell notes [14] that he found that reverse fault events gave accelerations that were 1.28 times stronger than non reverse fault events. Considering the mixture of source mechanisms in his data set, this suggests that reverse fault events may be approximately modelled by multiplying the right hand side of equation (6) by a factor of 1.2. Such a curve is therefore plotted on Figure 5 together with the mean $\pm \sigma$ curves and compared with the data points and mean regression curve for the two horizontal components for the Inangahua earthquake.

Further to the discussion of appropriate values of $d$ given above in relation to Figures 3 and 4 , for the regression analysis presented in Figure 4 it was assumed that $d=-1$. As for the Joyner and Boore model, it is seen that the Inangahua event is stronger than the mean $+\sigma$ values of the Campbell model over a substantial distance range, even making some allowances for this reverse fault effect.

It is noted that a similar reverse fault effect was observed recently in New Zealand intensity data [15], and possibly also in other PGA data [11].

Returning to the comparison with the Joyner and Boore model (Figure 4), we see that the Inangahua regression curve has PGA values which are about 1.8 to 2.5 times the predictions of the model at source distances of 20 to $100 \mathrm{~km}$. These ratios are within the range of similar ratios with the Joyner and Boore model found for seven other New Zealand earthquakes as discussed elsewhere [11].

Finally, based on a very simple site stiffness classification, no simple correlation between PGA and ground conditions could be seen in the attenuation plots. Joyner and Boore [9] also came to this conclusion regarding their American data. More data and more study is required to evaluate site effects.

\section{CONCLUSIONS}

The paper presents an important set of PGA data, previously inadequately reported, on the largest land-based New Zealand earthquake which has occurred in the era of strongmotion recording, i.e. the $M_{8} 7.4$ Inangahua earthquake of May 1968. The maximum PGA was approximately $0.6 \mathrm{~g}$ at a distance of $15 \mathrm{~km}$ from the fault. The attenuation regression curve for this data set gives PGA values of about twice those predicted by models of western USA data, a situation also found for seven recent New Zealand events in another study. 


\section{ACKNOWLEDGEMENTS}

The authors are grateful to their colleagues: $\mathbf{R}$ Hefford for assistance in researching the records, $\mathrm{N}$ Perrin for data on ground conditions, and $\mathrm{G}$ McVerry and $\mathrm{J}$ Zhao for their constructive in-house reviews.

\section{REFERENCES}

1. D.J. Dowrick and E.G.C. Smith (1990) "Surface wave magnitudes of some New Zealand earthquakes 19011988", Bulln. N.Z. National Soc. for Earthq. Eng., Vol. 23, pp198-210.

2. D.J. Dowrick (1991) "Magnitude reassessment of New Zealand earthquakes", Earthquake Engineering and Structural Dynamics, Vol. 20, pp577-596.

3. W.R. Stephenson (1968) "Inangahua earthquake engineering seismology", in "Preliminary reports on the Inangahua earthquake, New Zealand, May 1969" N.Z. Department of Scientific and Industrial Research Bulletin 193.

4. R.D. Adams, R.P. Suggate and R.I. Skinner (1968) "A note on the Inangahua earthquake", N.Z. JnL Geol. Geophys., Vol. 11, pp787-788.

5. R. Shepherd, T.A.H. Dodd, A.J. Sutherland, P.J. Moss, A.J. Carr, D.R. Gordon and A.H. Bryant (1970) "The 1968 Inangahua earthquake : report of the University of Canterbury survey team", Bulln Seism. Soc. of America, Vol. 60, pp1561-1606.

6. R Shepherd, A.H. Bryant, A.J. Carr, T.A.H. Dodd, D.R. Gordon, P.J. Moss, and A.J. Sutherland (1970) "The 1968 Inangahua earthquake", Canterbury Engineering Journal, University of Canterbury, No. 1, June.

7. G.H. McVerry (1986) "Uncertainties in attenuation relations for New Zealand seismic hazard analysis", Bulln. N.Z. National Soc. for Earthq. Eng., Vol. 19, pp28-39.
8. H. Anderson, S. Beanland, G. Blick, D. Darby, G. Downes, G. Eiby, J. Haines, J. Jackson, R. Robinson, $P$. Suggate, and T. Webb. "The Inangahua, New Zealand, earthquake : an integrated geological, geodetic and seismological source model", NZ Jnl. Geology and Geophysics (in press, 1993).

9. W.B. Joyner and D.M. Boore (1981) "Peak horizontal acceleration and velocity from strong-motion records including records from the 1979 Imperial Valley, California, earthquake", Bulln. Seism. Soc of America, Vol. 71, pp2011-2038.

10. N.N. Ambraseys and J.J. Bommer (1991) "The attenuation of ground accelerations in Europe", Earthquake Engineering and Structural Dynamics, Vol. 20, pp1179-1202.

11. D.J. Dowrick and S. Sritharan (1993) "Attenuation of peak ground accelerations in some recent New Zealand earthquakes", Bulln. N.Z. National Soc. for Earthq. Eng., Vol. 26, pp3-13.

12. H. Anderson, T. Webb, J. Jackson. "Focal mechanisms of large earthquakes in the South Island, New Zealand; implications for the accommodation of Pacific-Australia plate motion", Geophysical Journal International (in press, 1993).

13. T Webb (1992) Inst. of Geol. \& Nuclear Sciences, Wellington, pers. comm.

14. K.W. Campbell (1981) "Near-source attenuation of peak horizontal acceleration", Bulln. Seism. Soc. of America, Vol. 71, pp2039-2070.

14. D.J. Dowrick (1992) "Attenuation of Modified Mercalli intensity in New Zealand earthquakes", Earthquake Engineering and Structural Dynamics, Vol. 21, pp181-196. 